\title{
World in Deleuze's reconstruction of the ontology of univocity
}

\author{
Jing $A n$ \\ Nankai University, \\ 38, Tongyan Road, Tianjin, 300350, China
}

For citation: Jing An. World in Deleuze's reconstruction of the ontology of univocity. Vestnik of Saint Petersburg University. Philosophy and Conflict Studies, 2019, vol. 35, issue 1, pp. 32-42. https://doi.org/ 10.21638/spbu17.2019.103

Overcoming the tradition of metaphysics' forgetting of the world and restoring the principal status of the world is the fundamental assertion of the movement of $20^{\text {th }}$ century's philosophical cosmology, and the ontology of univocity which is the centrepiece of Deleuze's metaphysics of difference can be considered precisely as an important moment of this movement. Following the footsteps of Karl Löwith and Eugen Fink both of whom strive to surpass the traditional metaphysics in its medieval theological and modern subjectivist figures and think the World-Nature in a non-metaphysical manner, Deleuze has been well aware of the significance of Heraclitean original intuition of the world for the construction of ontology, that is to say, the ontology worthy of the name should be founded upon the World, be it cosmic or chaosmic, which is of a non-numerical unicity and of which both the divine and the human are only the modalities. Furthermore, he deepens this intuition through a reworking of Spinozism, especially the Spinozean theory of attributes as doubly infinite univocal forms and ultimately poses the Heraclito-Spinozean Nature-World as the common ontological condition of both the infinite and the finite and as the principle of individuation of all the intraworldy spatiotemporal beings. Hereby under the influence of the two German philosophers and through a deepening of their Heracliticism, Deleuze has established his own theory of World-Nature, i.e. ontology of univocity which has found its clearest and most profound expression in his creative interpretation of Spinoza's theory of attributes.

Keywords: world, cosmology, univocity, K. Löwith, E. Fink, J. Deleuze, Heraclitus, B. Spinoza.

What kind of philosophy does Deleuze bring to us? When Deleuze was still regarded as a "postmodern philosopher", the answers to this question may be "philosophy of becoming", "philosophy of desire", "philosophy of body", etc. However, as people nowadays have acknowledged that Deleuze is a metaphysician stricto sensu ${ }^{1}$, the answer to the above question became accordingly transcendental empiricism or ontology of immanence ${ }^{2}$. Compared with the post-modern characterizations of Deleuze's philosophical enterprise, the above answer, instead of staying on the level of derived consequences, focuses on the fundamental principles of Deleuzean metaphysics of difference: while transcendental empiricism exhibits the demand to go beyond the conditions of possible experience and give a genetic explanation of real experience or sensible being, ontology

${ }^{1}$ In a letter to Arnaud Villani, Deleuze famously writes: "Je me sens pur metaphysician" [I feel myself to be a pure metaphysician]. Cf. [1, p. 130].

2 This second kind of interpretation has found one of its finest expressions in Levy Bryant's brilliant book. Cf. [2].

(C) Санкт-Петербургский государственный университет, 2019 
of immanence reveals that both subjective consciousness and object as correlative of consciousness are only the empirical effects of the plane of immanence. However, is it still possible to give a third kind of response which, being not content with staying within the explicit framework of Deleuzean philosophy, attempts to regard it as a concrete expression or moment of a more wide-ranging general philosophical movement? Our answer is affirmative. Of course, we do not wish to include Deleuze into the "genealogy of minor philosophers" conceived by himself (e. g. the genealogy of minor post-Kantians of Maimon - Nietzsche - Bergson opposed to the genealogy of major post-Kantians of Fichte-Schelling-Hegel) as a lot of commentators are fond of doing, because doing this means still staying within the exoteric Deleuzean scheme. In contrast, our preferred answer is as the following: Deleuze's philosophy belongs essentially to the twentieth century's movement of philosophical cosmology the representatives of which, besides Deleuze, are Raymond Ruyer and Gilbert Simondon on the French side, Eugen Fink, Hans Jonas and Karl Löwith on the German side ${ }^{3}$. Generally speaking, this philosophical cosmology embraces the following three fundamental propositions: (1) World-Cosmos is Being, God conceived as center by medieval theology and Man conceived as center by modern metaphysics of subjectivity are nothing but modes of World-Being; (2) World is definitely not the aggregation of numerous empirical beings, but the (non-Kantian) transcendental condition which renders them possible. It is in this sense the productive and living principle of individuation; (3) World-Time is not the empirical succession of "nows", but a non-temporal eternity which renders possible the empirical passage of time. The aim of this paper is to demonstrate departing from this cosmological perspective that the ontology of univocity, centrepiece of Deleuzean metaphysics of difference, is an elaboration of the first two propositions of the philosophical cosmology. Moreover, we will show that this Deleuzean ontology of univocity is constructed through reviving the HeraclitoSpinozism. In order to uncover the problem of the world in Deleuze's philosophy, we will start from a later text of his which has received little attention from the scholars but is nonetheless of prime importance.

\section{The Philosophical Turning from the Original Infinitude to the Constituent Finitude Has Forgotten the Problem of World}

The turning from the philosophie à l'âge classique of seventeenth century to the modern philosophy of which Kantian transcendentalism is the representative is of fundamental importance in Deleuze's later thought. In his lecture course on Leibniz dated 20 May 1980, Deleuze considered this turning as that from the philosophy of infinitude the fundamental concern of which is to create the world like God to the philosophy of finitude which consists in the foundation within a world already there (or in Kantian terms: in the categorial determination of appearances in space and time $)^{4}$ like a hero. Later in two

${ }^{3}$ Czech philosopher Jan Patočka whose opus magnum Přirozený svět jako filosofický problém [The Natural World as a Philosophical Problem] has been translated into English recently should also be included [3]. It deserves mention that Pierre Montebello has given an excellent account of this philosophical cosmology, especially its French side, in his three important works. Cf. [4-6].

${ }^{4}$ In fact, the rudiment of this point is the following thesis concerning the turning from classical art to romantic art expounded in A Thousand Plateaus: distinguished from the classical artist who creates like God, the romantic artist founds like hero. Cf. [7, p.338-340]. 
of his Foucault lecture courses dated respectively 19 November 1985 and 26 November 1985, Deleuze provided a more elaborated account of this turning the essential of which has been integrated into the appendix of the 1986 published Foucault: "On the Death of Man and Superman" [8, p. 124-132]. Then how should we understand this significant philosophical turning?

Under the influence of Martin Heidegger and Jules Vuillemin, Deleuze believed that what characterizes the finitude which definitely became the fundamental problem of philosophy is the fact that the knowing subject is composed by two heterogeneous and equal faculties that are the receptive sensibility and the spontaneous understanding. By contrast, one of the fundamental theses of the philosophy of infinitude of seventeenth century is that sensibility is ultimately not an independent faculty but a secondary or derived form of understanding, that is to say, sensibility and understanding are homogeneous in principle; accordingly, sensible givens are no more than the secondary or derived figures of ideas or concepts belonging to the understanding [8, p. 124-127]. That being the case, what could be the ground of this thesis of infinitude? The answer to this question concerns the influence exerted upon the philosophie à lâge classique by Christian theology. In the framework of Christian theology, God's creation, creatio ex nihilo, involves no external matter and is distinguished for this reason from the act of creation of Demiurge described by Plato in Timaeus. If translating this theologico-metaphysical thesis into epistemological terms, we can obtain the following proposition: from the perspective of infinitude, the act of knowing or cognizing involves no sensible given from without. Philosophers are certainly finite creatures who have no access to the divine knowledge, this fact nevertheless does not prevent them from affirming that infinitude should be posed as the principle of cognition. In other words, although the human knowledge consists on the factual level in sensations and concepts, the former can be reduced in principle to the latter.

However, as we have already indicated, sensibility and understanding became in the Kantian philosophy of finitude two independent, heterogeneous and equal faculties which cannot be reduced to one another, and both the sensible givens and the intellectual concepts serve as the legitimate sources of cognition. So what's the significance of this? The fact that sensible givens have an irreducible existence means that man's act of knowing is not at all self-sufficient. Radically different from God who creates his objects of cognition by his infinite act of knowing, i. e. original intellectual intuition, man's finite act of knowing is conditioned by the already given external objects, that is to say, the insurmountable inner finitude itself became the principle. Moreover, the impotence to create the world form nothingness like God does not suggest that the human acts of knowing are purely and simply passive as they have their own way of acting transcendentally, that is to say, founding the world transcendentally, and this is precisely what is implicated in the wellknown Kantian formula "man is the law-giver of nature". Through pure spatial-temporal forms and categories of understanding, man as knowing subject constitutes the empirical world in the infinite continuum of space and time. God who creates the world from nothingness has retreated from view, Man who transcendentally founds the world became the center of philosophical landscape. As Deleuze has written by imitating Nietzsche's Zarathustra: Incipit Homo [8, p. 127].

In the following part of "On the Death of Man and Superman", Deleuze raises the following question: in our present times, after the God-centered âge classique and the Man- 
centered modern times, what should be taken as the foundation of contemporary philosophy? His own answer to this question is that it is Superman who provides us with the possibility of the future philosophy. However, if taking a closer look at Deleuze's exposition of the "historical formation" of modern thought, we could discover another question that has not been raised explicitly by Deleuze, a question of fundamental importance for our adequate understanding of his philosophy. As we have seen, with the transition from original infinitude to constituent finitude, the supreme place of God has been taken by Man, and the world changed accordingly from God's creation to Man's object of foundation. It is noteworthy that God, Man, and World are respectively the subjects of the three disciplines of metaphysica specialis, i. e., rational theology, psychology, and cosmology. Based on the above exposition, it is legitimate to claim that the history of philosophy can be interpreted to some extent as driven by the changing relationships between these three subjects. Nevertheless, although the relationship between God and Man has changed radically with the arrival of modern philosophy stricto sensu, World is still a pure passive being which, though not created by a transcendent God from nothingness, is founded or constituted by a transcendental Man-Subject. As for the active and founding origin, it seems that we could only make a choice between the infinite creating God or the finite founding Man. But is this alternative necessary? Does there exist the possibility that World can enjoy a supreme status? Or more precisely, can World become the priori condition of possibility of both God and Man? Can we expect on the philosophical level Incipit Mundus? We will lump all these questions together under the heading of the problem of world and demonstrate that the Deleuzean ontology of univocity is exactly a solution to this problem ${ }^{5}$. Of course, as we have mentioned at the beginning of this paper, the problem of the world is not confronted by Deleuze alone but a common subject for a number of twentiethcentury continental philosophers. Moreover, some of these philosophers have posed and elaborated the problem of the world in a manner much more direct than Deleuze, and two representatives of them are Karl Löwith and Eugen Fink. In order to elucidate the problem of the world and shed some light on the extent to which Deleuze has been inspired by his predecessor, we will give a brief account of Löwith's and Fink's discussions of the problem in the next section.

\section{A rediscovery of the Heraclitean Original Intuition of the World}

Whether conceived as divine creation in the framework of philosophie de l'âge classique or as object of transcendental foundation or constitution by Kant, the world as mechanical and extended physical nature is essentially devoid of life or spirit. If such a world is the result of the secularization, i. e. de-divination, of the Christian creationism, then the world understood in the scheme of Christianity as created and temporal results for its

\footnotetext{
${ }^{5}$ Indeed, when expounding his theory of univocal being, Deleuze himself never mentions explicitly the problem of world, but this does not mean that this problem is not important for him. Moreover, as we will see below, Deleuze's theory of univocal being can be legitimately seen as a response to this problem. And Deleuze himself declares many times that philosophers do not always tell us their problems that need to be discovered by commentators: "Philosophers introduce new concepts, they explain them, but they don't tell us, not completely anyway, the problems to which those concepts are a response... The history of philosophy, rather than repeating what a philosopher says, has to say what he must have taken for granted, what he didn't say but is nonetheless present in what he did say" [9, p. 136].
} 
part from the secularization of the Greek conception of the world - this is the conclusion drew by Karl Löwith on the basis of his Geistesgeschite studies [10, p. 305-306] ${ }^{6}$.

So, how was the world conceived before the first secularization of Christian creationism and the second secularization of modern philosophy of subjectivity? According to Löwith, the Greek conception of World finds its clearest expression in Heraclitus' Fragment 30 in Diel's collection of the Fragments of the Presocratics: "the world ( $\kappa$ o $\sigma \mu \mathrm{oc})$, the same for all, no god nor man has made, but it ever was and is and will be: fire everliving, kindled in measures and in measures going out" [12, p. 45] (translation modified). This Heraclitean original intuition reveals the three fundamental characteristics of the World: First, World is not "one" in the numerical sense of the word, because it does not coexist on the same level with the finite individual beings, that says, only the intraworldy beings have the numerically determined existences. In other words, it is neither an enormous worldthing nor an aggregation of numerous intraworldy things, but the universal condition which makes all the intraworldy beings to be what they are. It is precisely in this sense that the World can be called One [10, p. 296]; second, World is neither the creation of God nor the constitution of Man, it is, on the contrary, the priori condition of both God and Man. Neither is God world-transcending nor is Man the center of the world, because both of them are intraworldy beings [13, p. 8]; third, World is not subject to the passing time and advancing history on the human level, its nature is of the aeternitas which have nothing to do with the sempiternitas [10, p.302].

Based upon this Heraclitean original intuition, Löwith defines the world in the following manner: The World is "the One and Totality of all the beings from Nature (das Eine und Ganze alles von Natur aus Seienden)" [10, p. 296]. Such a divine and eternal world has been de-powered (depontenziert) and de-natured (denaturiert) by the Christian creationism [10, p. 305]: on the one hand, it has been deprived of its divinity and became consequently subordinated to God; on the other hand, it became the temporal and historicoexistential background of human beings who are now the image of God. Expressing no more the world-order, man must despise and abandon the world instead, because "anyone chooses to be a friend of the world becomes an enemy of God"; "if any man loves the world, the love of the Father is not in him." In the early stage of modern times, Descartes has laid the foundation for the modern understanding of the world by conceiving the already non-divine and temporal world as mechanical and extended. Although Husserl and Heidegger have attempted to go beyond Descartes by respectively conceiving the world

${ }^{6}$ Generally speaking, people are always conscious of the affinity between Fink's cosmological phenomenology and Heidegger's metaphysics of world. Alexander Schnell, for example, reminds us that "Heidegger s'intéressera à partir de 1927-1928, à la sphère qui rend possible l'ouverture à tout étant et que Heidegger continue à appeler le "monde" Nous verrons qu'il y a des indices évidents qui laissent à penser quả la fin des années 1920, Heidegger projetait de substituer une 'cosmologie', c'est-à-dire une métaphysique du monde, à la pensée de lêtre - une orientation qu'il a abandonée au profit d'une philosophie de l'histoire de lềtre et que son disciple Eugen Fink poursuivra, lui, après la Seconde Guerre Mondiale" (from 1927-1928, Heidegger will be interested in the sphere which makes possible the opening to all beings and which Heidegger continues to call the 'world'. We will see that there are clear indications which make one think that Heidegger, at the end of the 1920s, planned to substitute a 'cosmology', that is to say a metaphysics of world, for the thought of Being - an orientation which he abandoned in favour of a philosophy of history of Being and which will be pursued by his disciple Eugen Fink after the Second World War) [11, p.44-45]. What has always been overlooked however is that Löwith who is also a disciple of Heidegger's has established his own philosophy of World-Nature in a critical dialogue with Heidegger's theory of the world. 
as Totalhorizont and Weltentwurf, this nevertheless does not change the fact that World is still subordinated to Man [10, p. 295].

Of course, Löwith is not alone in being well aware of the importance of the Heraclitean original intuition. In Play as Symbol of the World, Eugen Fink attempted to construct a phenomenology of the world or phenomenological cosmology which takes as an object the world in itself and for itself ${ }^{7}$. It is noteworthy that the Finkian phenomenology of the world also highlights the significance of Fragment 30: "World-order, kosmos, is the beautiful dispensation of things and events that link them all together, that impresses a character of totality upon them and gathers them into a structured unity" [15, p. 49]. Like Löwith, Fink suggests that we should rule out two misunderstandings about the world: first, the world is neither an enormous extended being nor an aggregation of finite individual beings, it is strictly speaking non-thing or non-object; second, the world is neither a regulative Idea of subjective reason nor Dasein's constitutive determination or moment, as the emerging and the perishing of human subjects are only effects of the cosmic movement. That is to say, the world is "the total field of the actual. There is only one actuality, however many dimensions it may have. The one total actuality is not first assembled from many individual actual beings, however, but rather actuality tout court gathers together every individual-actual thing in advance" [15, p.83]. The world(-order) therefore is an infinite-dimensional totality which precedes ontologically all the parts that are the individual beings and serves as the latter's condition of possibility.

However, distinct from Löwith who seems simply affirm the world as "totality as such" and its independence from and priority in relation to God and Man, Fink further put forward the question of the relationship between the world and the intraworldy beings, i. e. that of the mechanism of individuation. According to Fink, it is the movement of individuation which characterizes the world not as static ready-made being but as an infinite power which produces and creates. Production and creation are thus life of the world: "The course of the world enjoins all individual beings; it allows them to emerge and perish, to grow and to shrivel; it brings things into their individuation and takes them away from it again - it occurs as the universal individuation (universelle Vereinzelung) of all finitely existing beings. The universal being-in-the-world of all finite things in general as belonging within the cosmos does not, therefore, mean a static, stationary relation, but rather the belonging of things within the prevailing of worldwide individuation, within the cosmic process of individuation" [15, p.72-73]. The reason why Christian theology deprived the world of its power of producing and creating is that it understands God as the sole creator of all the non-divine beings and treats the world once seen as infinite power of creation and individuation as a simple accumulation of the created individual beings. In this regard, both Löwith's and Fink's philosophies can be considered as efforts to restore the totality, infinity, eternity, and creativity of the world, that is to say, to restore the Heraclitean original intuition of the world.

We claim that Deleuze's philosophy belongs essentially to the genealogy of this philosophy of world or philosophical cosmology. If this is indeed the case, to what extent can we say that Deleuze's own consciousness of the problem has been influenced by Löwith and Fink? For Deleuze, Löwith is above all an outstanding interpreter of Nietzsche's philosophy. In his concluding remarks at the Royaumont Conference on Nietzsche held

\footnotetext{
${ }^{7}$ Cf. [14]. Fink's another important work can be considered as the prolegomena to this book. Cf. [15].
} 
in July 1964, Deleuze mentioned that Löwith analyzed "in a masterful presentation" the nature of nihilism and Nietzsche's effort to overcome nihilism. It deserves special mention that Deleuze highlighted Löwith's assertion that the manner in which Nietzsche goes beyond nihilism is through "a real recuperation of the world" [16, p. 120]. It is legitimately therefore for us to affirm that Deleuze is not at all ignorant of Löwith's theory of the world, at least in the form of Löwithian interpretation of Nietzsche's doctrine of the eternal return of the same. Deleuze's relation to Fink at the philosophical level, in comparison, is much more direct ${ }^{8}$. The latter's Play as a Symbol of the World has exerted upon Deleuze's early philosophy, especially his theory of Idée-Etre, an influence far from unimportant ${ }^{9}$. Moreover, if there exists in Deleuze some kind of Heraclitism, this must have been formed under the influence of Fink (and, to some extent, Kostas Axelos ${ }^{10}$ ).

Of course, this does not mean that Deleuze cannot raise the question of the world unless with the aid of Löwith's and Fink's works. It is of fundamental importance nevertheless to reveal at the factual level the affinity and similarity between thinkers who are often regarded as belonging to completely different camps. However, the affinity and similarity does not eliminate their remarkable difference: If Löwith and Fink attempt to restore the philosophical cosmology as philosophy of world through a return to Heraclitus' thought, Deleuze, for his part, has effectuated the restoration ultimately through a return to Spinoza (Moreover, as we will see below, Deleuze, like Schelling, Hölderlin, and Hegel before him, is well aware of the affinity between Spinoza and Heraclitus). Furthermore, while both Löwith's and Fink's philosophical cosmologies take "cosmos" or "world-order" as their leading concept, the fundamental concept posed by Deleuze is "chaosmos", i. e. Nature as the world "in which individuations are impersonal, and singularities are pre-individual" 11 . As we have seen, Löwith believes that the modern metaphysics of subjectivity which never breaks free from the influence of Christian theology implies a decrease in power of Nature-World. To this, Deleuze has given a perfect response in the conclusion of Spinoza and the Problem of Expression: Spinoza's philosophy is "a rediscovery of Nature and her power" and "a recreating of ontology". Thus, this ontology of nature, according to which "Being determined as God... expresses himself in the world", can be considered as "a new materialism" [20, p. 321] ${ }^{12}$. Such a philosophy in which Nature, Being, and World become one still has to face the Heraclitean question: how can the world, no god nor man has made, be the same for all? Deleuze's answer to this question is his theory of univocity of being.

${ }^{8}$ Dai Takeuchi has made a concise comparative study of the two philosophers in [17].

${ }^{9}$ Cf. [18, p. 197-199; 19, p. 58-65].

${ }^{10}$ See the two reviews written by Deleuze for the works of this famous French proponent of Heraclitean thought: "How Jarry's Pataphysics Opened the Way for Phenomenology" and "The Fissure of Anaxagoras and the Local Fires of Heraclitus", in [16, p. 74-76, 156-161].

${ }^{11}$ Cf. [18, p. xxi, 123-124, 199].

12 It is noteworthy that Löwith, when expounding Spinoza's idea of "world of nature (Welt der Natur)", has made an assertion quite similar to that of Deleuze's: "Die essentia Gottes oder der Natur schließt in dem Faktum ihrer extentia deren wesentliche potentia ein (The essentia of God or Nature implicates in the fact of its extentia its essential potentia)" [21, p.241]. 


\section{Deleuze's Heraclito-Spinozean Reconstruction of the Ontology of Univocity}

The ontology of univocity is of course not Deleuze's own invention. In Difference and Repetition, he locates the beginning of ontology of univocity in Duns Scotus [18, p. 39]. From the perspective of a common discourse of history of philosophy, the ontology of univocity itself is a solution to one of the central problems of medieval scholasticism: how can the finite understanding of human being acquire knowledge of God? The reason why Duns Scotus is against the theory of analogia entis endorsed by Thomas Aquinas and others and proposed his ontology of univocity is that only the latter can guarantee that man's finite understanding is capable of acquiring knowledge of God. Such being the case, can the ontology of univocity have any actual philosophical significance once abstracted from its theological context? As we have mentioned at the beginning of this paper, the first theme of Heraclitean cosmology is that both God and man are modes of World-Being. If we recall that in the philosophical context God stands for infinitude and man finitude, we can translate the above proposition into the following form: both "infinite" and "finite" are modes of World-Being. In this way, we can see clearly the relationship between Scotic ontology and Heraclitean cosmology as the univocal being conceived by Duns Scotus precisely has "infinite" and "finite" as its modus intrinsecus ${ }^{13}$. According to the mainstream theory of analogia entis in the scholasticism, although being of God and being of creatures share the same name "being", there's a difference in nature between the former's infinite being and the latter's finite being and it is because the latter serves as the former's analog that it can have its own being ${ }^{14}$. But in Duns Scotus' view, just as the difference of intensity between a deep red and a light red will not turn them into two different colors, infinite being and finite being, on the conceptual level, are nothing but two modalities or two intensities of one and the same being. However, in order to avoid pantheism, Duns Scotus only conceived abstractly univocal being as a neuter concept which is neither infinite nor finite in itself ${ }^{15}$, and the position he adopted on the level of reality is still that of the analogia entis. On the contrary, the significance of univocal being in the true sense of the words consists precisely in the affirmation not on the conceptual level but on the level of reality of the community of infinite being and finite being. Reconstructing the ontology of univocity after Duns Scotus means, therefore, realizing the transition from the conceptually neuter univocal being to the really affirmative univocal being; it is just for effectuating such a transition that Deleuze turned to Spinoza.

However, when elaborating the contribution made by Spinoza to the ontology of univocity in his Spinoza lecture course dated 24 March 1981, Deleuze took precisely as a point of departure the famous Heraclitean formula " $\tilde{\varepsilon} v \pi \alpha \dot{\alpha} v \tau \alpha$ (One-All)"16. According to him, "घี $v \pi \alpha \dot{v} \tau \tau$ " is the most fundamental ontological proposition whose philosophical consequence has found its purest and perfect expression in Spinoza's ontology the central proposition of which is Deus sive Natura. And the centerpiece of this Heraclito-Spinozean

${ }^{13}$ Cf. Ordinatio, I, dist. 8, pars. 1, qu. 3, n. 108, in [22, IV, p. 202-203; 20, p. 191].

${ }^{14}$ Cf. Summa theologia, Ia, qu. 44, a.1, in [23, IV, p. 455]; Summa contra Gentiles, I. 34, in [23, XIII, p. 103].

${ }^{15}$ Cf. Ordinatio, I, dist. 8, pars. 1, qu. 3, n. 81, in [22, p. 190; 18, p. 39].

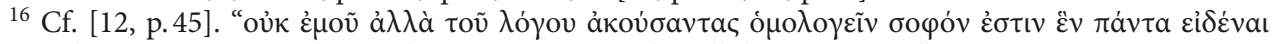
(It is wise, listening not to me but to the report, to agree that all things are one)". 
ontology is the theory of attributes which renders possible on the level of reality the univocal being: "Attributes are univocal or common forms, predicated, in the same form, of creatures and creator, products and producer, formally constituting the essence of one, formally containing the essence of the others" [20, p. 102-103]. In this regard, Nature-Being-Attributes, although conceived by Spinoza as strictly univocal, is definitely not a genus subsuming substance as infinite being and mode as finite being under itself as secondary concepts; it is, in fact, the reality constitutive both of the substance and the modes. On the one hand, the attributes are quantitatively infinite and as genetic elements constitute the substance as absolutely infinite Multiplicity. On the other hand, each attribute as an infinite quality is an actually infinite series which implicates within itself the modal essences as intensities or intensive parts which, although distinguished from one another, are indivisible ${ }^{17}$. If the crucial move by which Duns Scotus demonstrates the neutrality of being is to announce that the univocal being does not correspond to any reality, Deleuzean Spinozism's crucial move, on the contrary, is to affirm the full reality of univocal being, that is to say, to affirm that infinite being and finite being have their real and not simply conceptual community in the attributes.

If the theory of attributes provides by furthering the Scoticism an elaboration of the first thesis of philosophical cosmology according to which world is the "one" or "same" for all, then how to proceed with the second thesis concerning the principle of individuation? In fact, when declaring following Deleuze's interpretation of Spinozism that the attributes as univocal being implicate within themselves an infinity of intensive parts each of which is the singular essence of a finite individuated being, we have partially answered this question. Distinguished from the Aristotelian framework of specification within which the principle of individuation can only resort to the externality of accident or matter due to the impossibility of directly relating to being, Spinoza's Heraclitean onto-cosmology affirms that attributes as a principle of individuation relate directly to the individuals or more precisely individual or singular essences. In other words, being is the principle of individuation without the intermediation of genus or species. Furthermore, this HeraclitoSpinozean onto-cosmology determines the essences of all beings as a power which, unlike potential possibility, is always actual. Hence the attributes are a real ontological condition of the deploying of God's creative power, that is to say, the infinite substance produces an infinity of modes through the attributes and within the attributes. Accordingly, the attributes, rather than "containing" finite individual beings' essences statically, should be considered as expressing substance's infinite power dynamically ${ }^{18}$.

Let us conclude this paper by briefly summarizing our findings. As two representatives of the continental philosophical cosmology of the twentieth century, Löwith and Fink, both of whom have resorted to the Heraclitean original intuition of the world, have laid the foundation of an onto-cosmology which goes beyond the traditional metaphysics interpreted by Heidegger as onto-theology by determining the two fundamental characteristics of World-Nature: (1) it is of a non-numerical, i.e. transcendental unicity and can be understood therefore as a totum analyticum in the Kantian sense; (2) it is the principle of individuation of all the finite intraworldy beings. Under the influence of the two German philosophers and through a deepening of their Heracliticism, Deleuze has established his own theory of World-Nature, i.e. ontology of univocity which has

\footnotetext{
${ }^{17}$ Cf. [20, p. 196-198].

18 Cf. [20, p. 89-95].
} 
found its clearest and most profound expression in his creative interpretation of Spinoza's theory of attributes. According to this interpretation, (1) the attributes are ontological community (univocity) which is not neutral but real, they are the constitutive condition of the infinite substance on the one hand and, as actually infinite series, implicate within themselves the singular essences of the finite beings on the other hand; (2) the univocal being that is the attributes is the principle of individuation of all the intraworldy beings as it not only implicates the individual essences but is also that through which the absolutely infinite substance expresses the power as its inner nature and thus produces an infinity of modes.

\section{References}

1. Villani, A. (1999), La guêpe et l'orchidée [The Wasp and the Orchid], Berlin, Paris, France.

2. Bryant, L. (2008), Difference and Givenness: Deleuze's Transcendental Empiricism and the Ontology of Immanence, Northwestern University Press, Evanston, IL, USA.

3. Patočka, J. (2016), The Natural World as a Philosophical Problem, transl. by E. Abrams, Northwestern University Press, Evanston, IL, USA.

4. Montebello, P. (2003), L’autre métaphysique. Essai sur Ravaisson, Tarde, Nietzsche et Bergson [The Other Metaphysics: On Ravaisson, Tarde, Nietzsche and Bergson], Desclée de Brouwer, Paris, France.

5. Montebello, P. (2007), Nature et subjectivité [Nature and Subjectivity], Jérôme Millon, Grenoble, France.

6. Montebello, P. (2016), Métaphysiques cosmomorphes. La fin du monde humain [Cosmomorphic Metaphysics: End of the Human World], Les presses du réel, Paris, France.

7. Deleuze, G. and Guattari, F. (1987), A Thousand Plateaus, transl. by Massumi, B., University of Minnesota Press, Minneapolis, MN, USA. USA.

8. Deleuze, G. (1988), Foucault, transl. by Hand, S., University of Minnesota Press, Minneapolis, MN,

9. Deleuze, G. (1995), Negotiations 1972-1990, transl. Joughin, M., Columbia University Press, New York, NY, USA.

10. Löwith, K. (1981), "Welt und Menschenwelt" [World and Man's World], in Mensch und Menschenwelt: Beiträge zur Anthropologie [Man and Man's World: Contributions to Anthropology], Metzler, Stuttgart, Germany, pp. 295-328.

11. Schnell, A. (2005), De l'existence ouverte au monde fini. Heidegger 1925-1930 [From the Opened Existence to the Finite World: Heidegger 1925-1930], Vrin, Paris, France.

12. Kahn, Ch. H. (1979), The Art and Thought of Heraclitus, Cambridge University Press, Cambridge, UK.

13. Löwith, K. (1968), Der Weltbegriff der neuzeitlichen Philosophie [The Concept of World of Modern Philosophy], Carl Winter Universitätsverlag, Heidelberg, Germany.

14. Fink, E. (2016), Play as Symbol of the World and Other Writings, transl. by Moore, I. A. and Turner, Ch., Indiana University Press, Bloomington and Indianapolis, IN, USA.

15. Fink, E. (1990), Welt und Endlichkeit [World and Finitude], Königshausen und Neumann, Würzburg, Germany.

16. Deleuze, G. (2003), Desert Islands and Other Texts (1953-1974), transl. by Taormina, M., Semiotexte, New York, NY, USA.

17. Takeuchi, D. (2011), “Zweideutigkeit des Meon und Kosmologie als Phänomenologie der Immanenz. Fink und Deleuze" [Ambiguity of Non-Being and Cosmology as Phenomenology of Immanence: Fink and Deleuze], in Nielsen, C. and Sepp, H. R., eds, Welt denken. Annäherungen an die Kosmologie Eugen Finks [Thinking the World: Approaches to the Cosmology of Eugen Fink], Verlag Karl Alber, Freiburg, München, Germany, pp. 237-249.

18. Deleuze, G. (1994), Difference and Repetition, transl. by Patton, P., Columbia University Press, New York, NY, USA.

19. Deleuze, G. (1990), The Logic of Sense, transl. Lester, M. with Stivale, Ch., Columbia University Press, New York, NY, USA.

20. Deleuze, G. (1990), Expressionism in Philosophy: Spinoza, transl. by Joughin, M., Zone Books, New York, NY, USA. 
21. Löwith, K. (1967), Gott, Mensch und Welt in der Metaphysik von Descartes bis zu Nietzsche [God, Man and World in the Metaphysics from Descartes to Nietzsche], Vandenhoeck \& Ruprecht, Göttingen, Germany.

22. Scotus, D. (1056), Opera Omnia Joannis Duns Scoti [Complete Works of John Duns Scotus], ed. by Balić, P. C., Civitas Vaticana, Rome, Italy.

23. Aquinas, Th. (1888). Sancti Thomae de Aquino Opera Omnia [Complete Works of St. Thomas Aquinas], issu Leonis XIII edita cura, Typographia polyglottap, Rome, Italy.

Recived: July 10, 2018

Accepted: 3 October, 2018

Author's information:

Jing An — PhD, Lecturer; anjing@nankai.edu.cn

\section{Мир в делёзовской реконструкции онтологии однозначности}

\section{Цзин Ан}

Нянькайский университет,

Китайская Народная Республика, 300350, Тяньцзинь, дорога Тонгян, 38

Для цитирования: Цзин Ан. Мир в делезовской реконструкции онтологии однозначности // Вестник Санкт-Петербургского университета. Философия и конфликтология. 2019. Т. 35. Вып. 1. С. 32-42. https://doi.org/10.21638/spbu17.2019.103 (In English)

В данной статье эксплицируется онтология единства как центральный элемент метафизики различия Делёза, рассматриваемой автором в контексте движения философской космологии ХХ в. В преодолении традиции метафизического забвения мира и восстановлении статуса мира в современной философии Делёз следует за К. Левицем и О.Финком, которые стремились превзойти традиционную метафизику в ее средневековых богословских и новоевропейских субъективистских образцах. В отличие от названных выше мыслителей, трактовавших мир-природу в неметафизическом ключе, сам Делёз отчетливо понимал важность оригинальной интуиции греческого философа Гераклита для построения онтологии. Онтология, достойная собственного названия, должна основываться на Мире, космическое (упорядоченное) или хаотическое бытие которого имеет нечетную единственность, тогда как божественное и человеческое являются лишь ее модальностями. Автор приходит к выводу о том, что Делёз реактуализирует и углубляет гераклитовскую интуицию за счет переосмысления спинозизма, особенно спинозовской теории атрибутов как двумерно бесконечных однозначных форм субстанции-Природы. Тем самым гераклито-спинозианский Мир-природа постулируется Делёзом, во-первых, как общее онтологическое состояние бесконечного и конечного и, во-вторых, как принцип индивидуации всех внутримирных пространственно-временных существ. Таким образом, под влиянием двух немецких философов - К. Левица и О. Финка и углубляя их гераклитовскими идеями Делёз создал свою собственную теорию мира-природы или онтологию единственности, которая нашла свое наиболее ясное и глубокое выражение в его творческой интерпретации теории атрибутов Б. Спинозы.

Ключевые слова: мир, космология, однозначность, К.Левиц, О.Финк, Ж.Делёз, Гераклит, Б. Спиноза.

Контактная информация:

Цзин Ан - PhD, лектор; anjing@nankai.edu.cn 